\title{
CORPORATE GOVERNANCE, CORPORATE SOCIAL RESPONSIBILITY AND CORPORATE SUSTAINABILITY: THE MODERATING ROLE OF TOP MANAGEMENT COMMITMENT
}

\section{Isaac TandohA, Kwame Asare Duffour ${ }^{\mathrm{B}}$, Mavis Essandohc,} Richard Nana AmoakoD

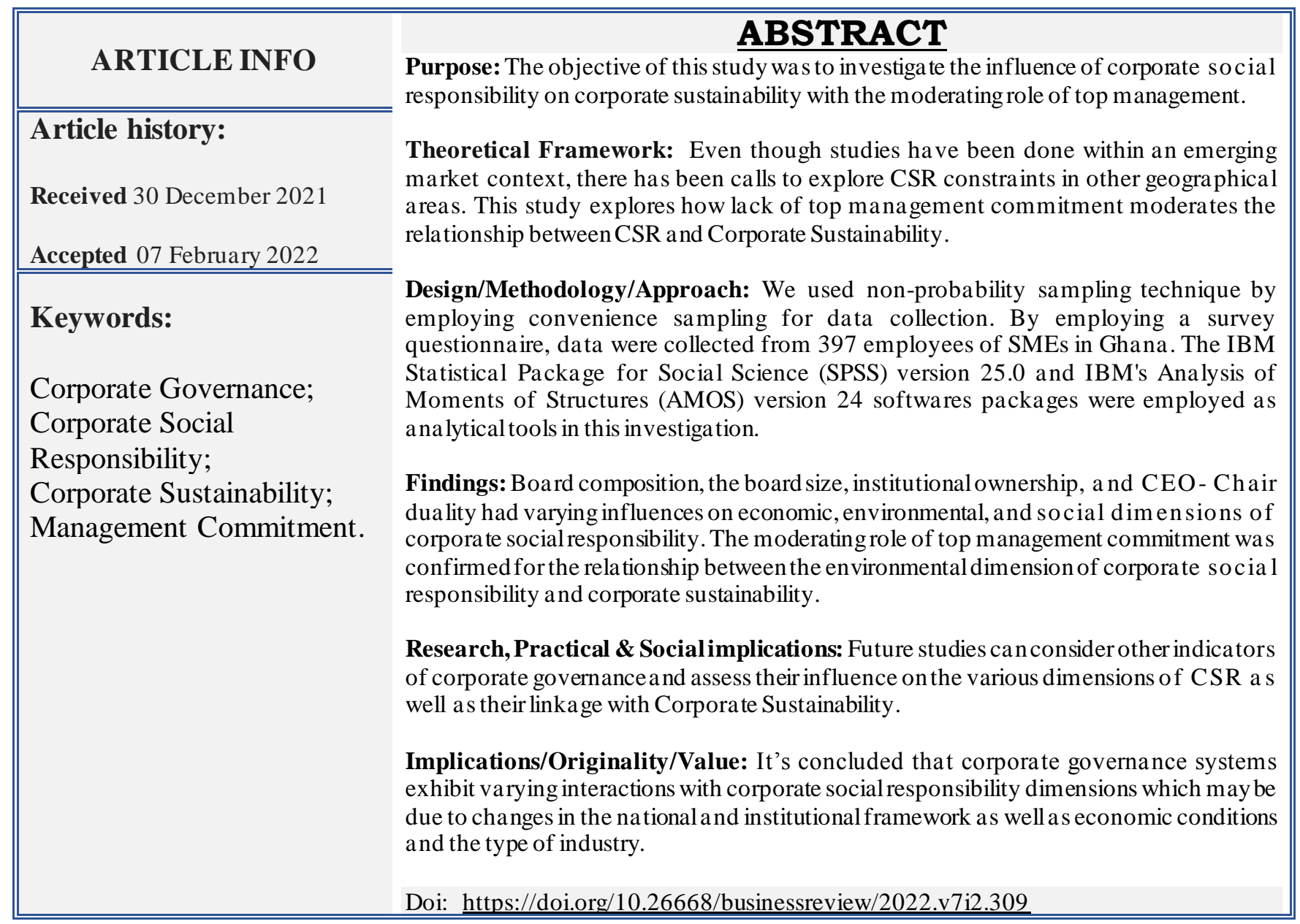

A PhD in Management with a focus on Integrated Marketing Communication from University of Nicarágua (UCN), Managua, Nicarágua. He is a Lecturer at the Faculty of Public Relations, Advertising and Marketing at Ghana Institute of Journalism (Ghana).Email: iketandy@gmail.com Orcid: http://orcid.org/0000-0003-3878-9716

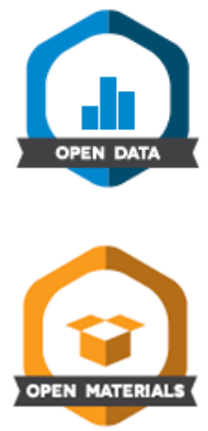

${ }^{B} \mathrm{PhD}$ in Management with a focus on Corporate Social Responsibility and Sustainability from Zhejiang Gongshang University, Hangzhou, China. He is a Lecturer in Management and Organizational Behavior, Principles of Management, and Basic Management in the Management Studies Department at Kumasi Technical University (Ghana). Email: duffour24@gmail.com Orcid: https://orcid.org/0000-0001-6444-7221

${ }^{C}$ PhD with a focus on Community Journalism and Public Relations from Deakin University, Victoria, Australia. She is a Senior Lecturer as well as the Acting Dean of the Faculty of Public Relations (PR), Advertising and Marketing in Ghana Institute of Journalism (Ghana). Email: mavisessandoh@yahoo.com Orcid: https://orcid.org/0000-0001-5883-5340

D Master of Arts in Development Communication from Ghana Institute of Journalism, Accra (Ghana). A graduate from the Faculty of Public Relations (PR) Advertising and Marketing at Ghana Institute of Journalism (Ghana). Email: richamoako@aol.com Orcid: https://orcid.org/0000-0001-7144-4336 


\section{GOVERNANÇA CORPORATIVA, RESPONSABILIDADE SOCIAL CORPORATIVA E SUSTENTABILIDADE CORPORATIVA: O PAPEL MODERADOR DO COMPROMISSO DE ALTA GESTÃO}

\section{RESUMO}

Objetivo: O objetivo deste estudo foi investigar a influência da responsabilidade social corporativa na sustentabilidade corporativa com o papel moderador da alta gestão.

Estrutura Teórica: Embora estudos tenham sido feitos dentro de um contexto de mercado emergente, houve apelos para explorar restrições de RSE em outras áreas geográficas. Este estudo explora como a falta de comprometimento de alta gestão modera a relação entre A RSE e Sustentabilidade Corporativa.

Design/Metodologia/Abordagem: Utilizamos técnica de amostragem sem probabilidade, utilizando amostragem de conveniência para coleta de dados. Por meio da utilização de um questionário de pesquisa, foram coletados dados de 397 funcionários de ESM em Gana. Os pacotes de softwares $25.0 \mathrm{~d}$ a IBM Statistical Package for Social Science (SPSS) e a análise de momentos de estruturas (AMOS) da IBM foram emprega dos como ferramentas analíticas nesta investigação.

Achados: A composição do conselho, o tamanho do conselho, a propriedade institucional e a dualidade ceo-chair tiveram influências varia das nas dimensões econômica, ambientale social da responsabilida de social corporativa. O papel modera dor do compromisso de alta gestão foi confirmado para a relação entre a dimensão a mbiental da responsabilidade social corporativa e a sustentabilidade corporativa .

Pesquisa, Implicações Práticas \& Sociais: Estudos futuros podem considerar outros indicadores de governança corporativa e avaliar sua influência nas diversas dimensões da RSE, bem como sua ligação com a Sustentabilidade Corporativa.

Implicações/Originalidade/Valor: Conclui-se que os sistemas de governança corporativa apresentam interações variadas com dimensões de responsabilidade social corporativa que podem ser devido a mudanças no quadro nacionale institucional, bem como nas condições econômicas e no tipo de indústria.

Palabras clave: Governança Corporativa; Responsabilidade Social Corporativa; Sustentabilidade Corporativa; Compromisso de Gestão.

\section{GOBIERNO CORPORATIVO, RESPONSABILIDAD SOCIAL CORPORATIVA Y SOSTENIBILIDAD CORPORATIVA: EL PAPEL MODERADOR DEL COMPROMISO DE LA ALTA DIRECCIÓN}

\section{RESUMEN}

Propósito: El objetivo de este estudio fue investigar la influencia de la responsabilidad social corporativa en la sostenibilidad corporativa con el papelmoderador de la alta dirección.

Marco teórico: A pesar de que los estudios se han realizado dentro de un contexto de mercado emergente, ha habido llamados a explorar las limitaciones de la RSE en otras áreas geográficas. Este estudio explora cómo la falta de compromiso de la alta dirección modera la relación entre la RSE y la Sostenibilidad Corporativa.

Diseño/Metodología/Enfoque: Se utilizó la técnica de muestreo no probabilístico empleando el muestreo de conveniencia para la recolección de datos. Mediante el empleo de un cuestionario de encuesta, se recopilaron datos de 397 empleados de PYME en Ghana. Los paquetes de software IBM Statistical Package for Social Science (SPSS) versión 25.0 y Analysis of Moments of Structures (AMOS) versión 24 de IBM se emplearon como herramientas analíticas en esta investigación.

Hallazgos: La composición de la junta, el tamaño de la junta, la propiedad institucional y la dualidad CEO-Presidente tuvieron diversas influencias en las dimensiones económicas, ambientales y sociales de la responsabilidad social corporativa. Se confirmó el papel moderador del compromiso de la alta dirección para la relación entre la dimensión ambiental de la responsabilidad social corporativa y la sostenibilidad corporativa.

Investigación, implicaciones prácticas y sociales: Los estudios futuros pueden considerar otros indicadores de gobierno corporativo y evaluar su influencia en las diversas dimensiones de la RSE, así como su vinculación con la sostenibilidad corporativa.

Implicaciones/Originalidad/Valor: Se concluye que los sistemas de gobierno corporativo exhiben interacciones variables con las dimensiones de responsabilidad social corporativa que pueden deberse a cambios en el marco nacional e institucional, así como a las condiciones económicas y el tipo de industria.

Palabras clave: Gobierno Corporativo; Responsabilidad Social Corporativa; Sostenibilidad Corporativ a ; Compromiso de gestión. 


\section{INTRODUCTION}

Today's businesses have moved beyond the traditional view of profit maximization and have restructured their operations to place a greater emphasis on the impact of their operations on society and the environment (Ashrafi et al., 2020). As a result, organizations are identifying ways to implement strategies that will result in a positive and sustainable relationship with stakeholders (Lozano, 2015). This shift in emphasis away from profit objectives and toward organizations' contributions to society and the environment has resulted in the emergence of corporate social responsibility and corporate sustainability (Ashrafi et al., 2020). Corporate social responsibility (CSR) has been described as a way of showing a corporation's concern and commitment towards society (Ashrafi et al., 2018) and emphasizes on responsibilities of corporations beyond what the law or legislation requires them to do (Pintea, 2015). CSR aims to maximize the shared value of both shareholders and stakeholders (Carroll et al., 2015). CSR is important for the growth and development of organizations, empowerment, and improvement of the living standards of the community, as well as contributing to the development of inhabitants in the community (Amoako, 2017). Ghanaian executives seem to have positive attitudes toward CSR, which are heavily influenced by both individual and societal ethical values (Ofori, 2008). Managers and executives in Ghana, on the other hand, participate in CSR initiatives first to improve their company image among their consumers and, moreover, for the well-being of society. According to Ofori (2008), Ghanaian managers prioritize social need s above corporate rewards as the most significant influencers of CSR concerns. He also stated that in his study, 61 percent of managers stated that the most important benefit they derive from CSR activities is an improvement in their company's image, compared to only 15 percent and 4 percent who stated that the most important benefits they derive from CSR activities are an increase in sales of goods and financial rewards.

The literature is replete with studies of CSR, examining its activities and typologies. CSR has been found to be achieved through various practices, such as ensuring good corporate citizenship, maintaining strong corporate governance, reporting on corporate performance, making socially responsible investments, and behaving ethically in a general sense (Ratnasari et al., 2021; Ashrafi et al., 2018). Ashrafi et al. (2018) called for additional research to examine how the concepts of CSR and CS are 
connected to corporate activities to ensure consistency and accuracy when addressing various issues. The implementation of CSR as well as sustainable practices have been found to be fraught with several challenges such as lack of top management commitment (Goyal \& Kumar, 2017) ; lack of CSR knowledge (Goyal \& Kumar, 2017; Raut, 2018); lack of resources (Bux et al., 2020; Zou et al., 2021); complexity of CSR issues ( Goyal \& Kumar , 2017); lack of regulations (Bux et al., 2020; Zou et al., 2021)), high cost of CSR initiatives (Zhang et al., 2018) and indifference on the part of customers (Bux et al., 2020; Zou et al., 2021). This study explores how lack of top management commitment moderates the relationship between CSR and CS. The study attempts to fill the paucity of the empirical literature on the linkage between CSR and CS within a developing economy such as Ghana. The study contributes to the extension of the literature on CSR and CS. For practitioners, the examination of the various aspects of CSR and its influence on CS is crucial for the development of an effective corporate as this study highlights the key factors that drive CS.

The present study introduction contains background to the research, research problem, the objective of the study, and highlights significance of CSR to management. This is followed by theories and a review of empirical literature that have characteristically underpinned CSR and CS research. The research strategy employed, sampling method and procedure, questionnaire development and the scales used to measure the various constructs were elaborated. Finally, the study presents a discussion on the findings, the theoretical and practical implications, as well as limitations of the study, and potential areas for future research.

\section{LITERATURE REVIEW}

\section{The Concept of CSR}

The concept of corporate social responsibility dates all the way back to the 1920 s, when it was incorporated into the concepts of corporate philanthropy, social give-back, codes of conduct, community service, and business executives as public trustees (Frederick, 2006). However, the notion of CSR did not gain traction among large firms until the 1950s, owing to the Great Depression of the 1930s and World War II in the 1940s (Carroll \& Shabana, 2010). Nonetheless, CSR came to prominence in 1951, when Frank W. Abrams, a former executive for Standard Oil Company of New Jersey, proposed that enterprises be held accountable for their activities to society and that business managers should manage the enterprise in their care in such a way that an 
equitable and workable balance is maintained between the claims of the many interested groups: investors, employees, customers, and the general public. (Ashrafi et al., 2020). CSR has moved from more of a social/philanthropic focus to a more holistic view of social, environmental, and economic responsibilities (Ashrafi et al., 2018; Sarkar \& Searcy, 2016). This is an important concept for both academics and practitioners as CSR has been found to have a significant impact on business image revalorization with employees and customers and creates an internal dynamic to the company's internal image as well as makes it possible to provide a positive image towards the customers' external image (Arrive et al., 2019). CSR has been widely adopted as a business strategy to enhance corporate image and reputation (Arrive et al., 2019).

\section{THEORETICAL REVIEW AND HYPOTHESES DEVELOPMENT Agency Theory}

The agency theory is one of the dominant theories that has dominated research about boards of directors (García-Meca \& Palacio, 2018). According to the agency theory, a manager will behave in his or her own best interest, not the best interest of the shareholders, and that manager may be motivated to take activities that benefit the manager but are costly to the shareholders (Kyere \& Ausloos, 2021). The agency theory details the relationship between the managers (agents) and the shareholders (principals) (Donaldson \& Davis, 1991). According to the agency theory, the board of directors can monitor effectively if they are independent from the management (Beasley, 1996; Christensen et al., 2010) and that the absence of controls could have dire consequences that could lead to market failures, non-existence of the markets, moral hazards, asymmetric information, incomplete contracts, and moral selection (Kyere \& Ausloos, 2021). The argument is that incentives exist for outside directors to protect their reputations, which motivate them to exercise decisional control (Christensen et al., 2010). Therefore, this theory argues that corporations have a chance to increase financial performance if costs are minimized (Kyere \& Ausloos, 2021). The theory argues that the strong relationship between managers and shareholders enhances the resolution of divergent interests between the management of the organization and the owners, prescribing ways of resolving such conflicts, like delegating decision-making authority to the agents who manage a project (Kyere \& Ausloos, 2021; Dewi et al., 2021). Based on Agency Theory, it is argued that the separation of board chair and CEO roles can enhance the independence of the board of directors from management 
(Michelon \& Parbonetti, 2012), as this will ensure proper check and balances between the CEO and the chairperson. Jo and Harjoto (2012) conducted a comparison of the applicability of stakeholder and agency theories to the causal consequences of corporate governance and CSR participation. From a stakeholder perspective, corporate financial performance is a function of CSR participation rather than agency. While Jo and Harjoto (2012) study confirmed the stakeholders' perspective, it can be broadened by including the corporate governance idea.

\section{Corporate Governance (CG) and Corporate Social Responsibility (CSR)}

Literature is replete with studies that have examined the link between corporate governance and CSR. Jo and Harjoto (2012) revealed that the lag of corporate governance variables positively affects firms' CSR engagement. Previous studies have shown how the various components of corporate governance influence CSR performance. For instance, a study by Stuebs and Sun (2015) found that corporate governance (which was assessed using board structure and composition; audit issues; charter and bylaw provisions; laws of the state of incorporation; executive and director compensation; qualitative factors; director and officer stock ownership; and director education) had a positive influence on CSR. Empirical studies involving the CSR characteristics that are being considered for this study and CSR are discussed below.

\section{Board Composition and Corporate Social Responsibility (CSR)}

Previous studies on the influence of board composition and CSR have produced mixed results with most of these studies being conducted in developed countries than emerging markets (Karim et al., 2020). Karim et al.(2020) found that there is weak linkage between board composition and CSR practices. Furthermore, board composition can have a negative influence on CSR performance as board ideological diversity have been found to have a negative relationship with CSR performance, indicating that a high level of ideological diversity leads to a lower performance in CSR (Olthuis \& van den Oever, 2020). However, a study by Lau et al.( 2016) found that the relationship between board composition and CSR was not significant. Nevertheless, based on the stakeholder theory, this study expects that board composition will have a positive influence on all the dimension of CSR. It is therefore hypothesized that: Hla: Board Composition is positively and significantly related to economic CSR 
H1b: Board Composition is positively and significantly related to environmental CSR H1c: Board Composition is positively and significantly related to social CSR

\section{Board Size and Corporate Social Responsibility (CSR)}

Previous studies have churned out contradictory findings regarding the relationship between board size and CSR (Rouf \& Hossan, 2021). A study of 91 public listed companies from Bursa Malaysia by Alabdullah et al. (2019) revealed that board size had a significant and positive relationship with CSR disclosure. Another study by Zhuang et al. (2018) revealed that board composition, which was measured with aspects such as political experience, academic experience, overseas background, and gender diversity, has a positive relationship with firms' CSR performance. Abu Qa'dan \& Suwaidan (2019) found board size to be significantly and positively associated with CSR disclosure levels. Yet in another study, board size was found to have no significant relationship with CSR disclosure (Rouf \& Hossan, 2021). Based on the stakeholder theory, this study argues that board size will have a positive relationship with all the dimensions of CSR. It is therefore hypothesized that:

H2a: Board size is positively and significantly related to economic CSR

$H 2 b$ : Board size is positively and significantly related to environmental CSR

$H 2 c$ : Board size is positively and significantly related to social CSR

\section{Institutional Ownership and Corporate Social Responsibility (CSR)}

Empirical evidence pointing to the relationship between institutional ownership and CSR has been mixed (Erhemjamts \& Huang, 2019). Some researchers have argued that high level of institutional ownership will have a negative influence CSR (e.g. Brickley et al. (1988), Dalton et al. (2003), Hoskisson et al. (2002) while others have argued for a positive influence of institutional ownership on CSR (e.g., Jensen \& Meckling,1976). However, some other authors have found that institutional ownership exhibits non-linear effects on CSR (Oh et al., 2017). Erhemjamts and Huang (2019) found that institutions with shorter investment horizons CSR at the firm level and that the higher the proportion of long-term investors, the higher the effect of CSR on longterm buy-and-hold returns. And yet another study, Nurleni et al. (2018) found that there is a positive and significant relationship between institutional ownership on CSR 
disclosure. Based on the above discussion, this study posits that institutional ownership will have a positive influence CSR. It is therefore hypothesized that:

H3a: Institutional ownership is positively and significantly related to economic CSR

H3b: Institutional ownership is positively and significantly related to environmental CSR

H3c: Institutional ownership is positively and significantly related to social CSR

\section{CEO-Chair and Corporate Social Responsibility (CSR)}

Al-Baddullah et al. (2018) found that CEO-Chair duality has been found to have a negative relationship with CSR disclosure. Another study by Abu Qa'dan and Suwaidan (2019) found that duality of CEO and chairman positions had negative influence on CSR disclosure level. CEO-Chair duality has been shown to have a detrimental effect on CSR activities, since CEOs have been shown to be more profitdriven and to pursue profits more aggressively at the expense of CSR efforts (Zhang, 2012). Based on previous studies, it is therefore hypothesized that:

H4a: CEO-Chair Duality is negatively and significantly related to economic CSR

H4b: CEO-Chair Duality is negatively and significantly related to environmental CSR

H4c: CEO-Chair Duality is negatively and significantly related to social CSR

\section{Corporate Social Responsibility (CSR) and Corporate Sustainability (CS)}

CSR and CS are both "voluntary business activities" that aim to contribute to the better performance of corporations in social, environmental, and economic spheres (Lo, 2010). A study by Sharma and Khanna (2014) found that there was a positive low and insignificant correlation between corporate governance and sustainability. According to Ashrafi et al. (2018), CSR acts as a transitional stage is when a corporation moves through the spectrum towards sustainable development, so that it might go beyond what laws and regulations require them to do, yet not necessarily encompasses comprehensive sustainable activities. It is therefore hypothesized that the existence of CSR activities would contribute positively to corporate sustainability goals. It is therefore hypothesized that: 
H5a: Economic CSR is positively and significantly related to corporate sustainability

H5b: Environmental CSR is positively and significantly related to corporate sustainability

H5c: Social CSR is positively and significantly related to corporate sustainability

\section{Moderating Role of Top Management Commitment}

The successful realisation of any goal of an organisation is dependent upon the commitment of its top management (Williams et al., 2014). Therefore, the promotion of sustainability, which can lead to competitive advantage, lies within the commitment of managers towards these sustainable practices (Yang Spencer et al., 2013). A study by Yusliza et al. (2019) found that CSR has a significant positive relationship with top management commitment and CS. According to Goyal and Kumar (2017), commitment from top executive of the organization is critical for successful implementation of CSR initiatives. The authors argued that the lack of top management commitment is one of the factors that hinders a successful implementation of CSR as the CEOs' political ideologies will influence their firms' CSR. In addition, commitment from top management may also motivate others to ensure the effective implementation of CSR in the organization. It can therefore be argued that the commitment of top management may moderate the relationship between CSR and CS. It is therefore hypothesised that:

H6a: Top management will moderate the relationship between Economic CSR and corporate sustainability such that the higher the level of commitment, the stronger the relationship between CSR and CS

H6b: Top management will moderate the relationship between Environmental CSR and corporate sustainability such that the higher the level of commitment, the stronger the relationship between CSR and CS

H6c: Top management will moderate the relationship between Social CSR and corporate sustainability such that the higher the level of commitment, the stronger the relationship between CSR and CS 


\section{Conceptual Model}

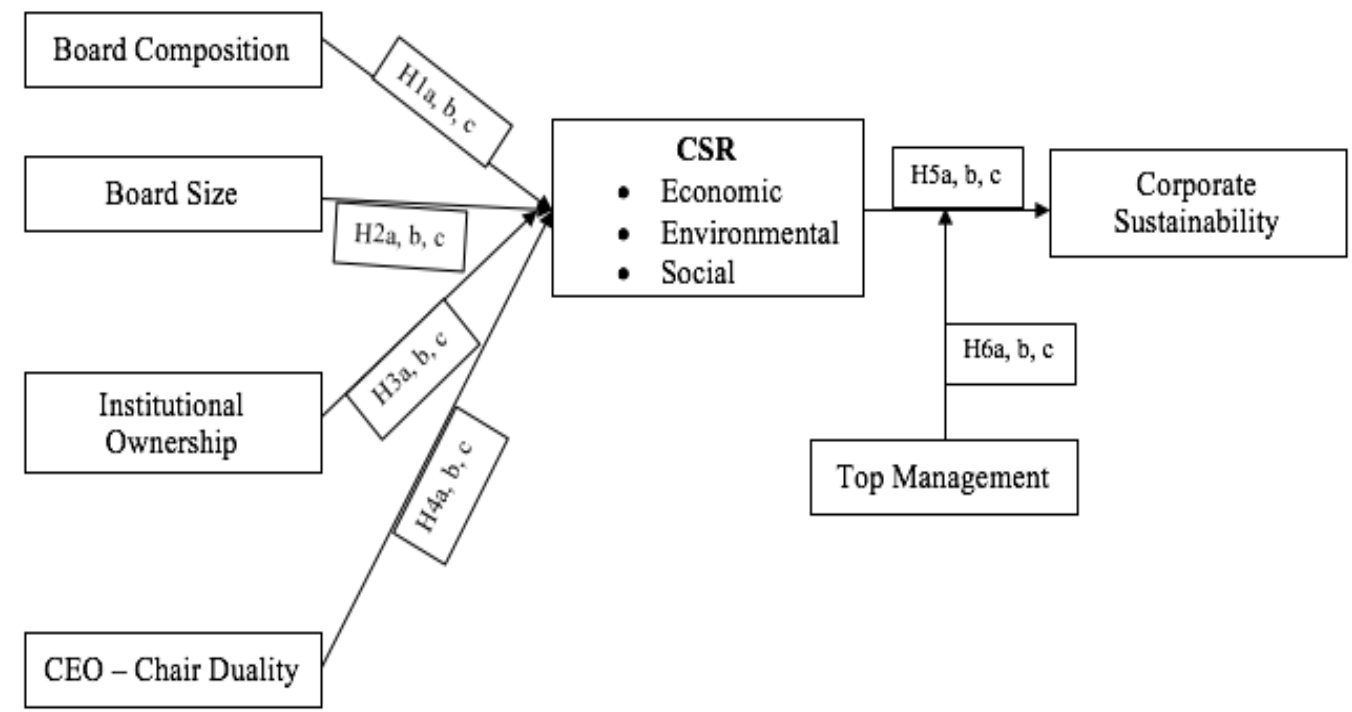

Figure 1: Conceptual Model Source: Researchers own construction

\section{METHODOLOGY}

Participants, Procedure and Measurement

Quantitative research approach or methodology gives emphasis to quantification in both data collection and analysis (Bryman, 2008). In the current study, the quantitative research approach is adopted based on the study's objectives and the paradigm of choice which requires such an approach. The current study adopted a crosssectional research design. Cross-sectional research is the most frequently used type of descriptive design (Churchill and Iacobucci, 2002; Malhorta and Birks, 2007). This study adopted the survey strategy in as a primary tool for data collection as this strategy is relatively inexpensive and has the ability of describing large population characteristics and eliminating observer subjectivity by presenting all study subjects with standardized stimulus which helps in turn in obtaining higher reliability (Palmquist, 2011). The target population for this study consists of employees and management of SMEs in Accra. The present study adopted non-probability sampling technique by employing convenience sampling. For this study, primary data for testing the hypothesis were collected via self-administered questionnaires staff of these SME's and the secondary data included information retrieved from databases and publications to guide the researcher in the primary data collection (Webb, 2000). The IBM Statistical Package for Social Science (SPSS) version 25.0 and IBM's Analysis of Moments of 
Structures (AMOS) version 24 software packages were employed as analytical tools in this investigation.

Consistent with prior studies (e.g., (Appelbaum et al., 2000; Jiang et al., 2012; Lepak et al., 2006), CSR measures adopted in the present study were divided into three dimensions. In all fourteen items were used to measure employee comprehension of CSR dimension. These items were drawn from previous studies. Corporate governance was measured was measured with items adapted from Brown \& Caylor (2006). The various dimensions of CSR were measured based on the items adapted from studies from Alvarado-herrera et al. (2017) proposed by Turker (2009) and Jizi et al. (2013). Corporate sustainability was measured with a five-item scale adapted from Chow \& Chen (2012). Top management commitment was measured on a three-item scale that was adopted from Erdogan et al. (2015). These items were anchored on a Likert scale from 1 to 5 , where 1 corresponded to "strongly disagree" (1) and 5 corresponded to "strongly agree" (5).

\section{DATA ANALYSIS Demographic Description}

The majority of the respondents in Ghana are females $(51.1 \%, \mathrm{n}=203)$ whilst the males were $48.8 \%(n=194)$. As regards the educational qualifications of the respondents, the majority of the respondents possessed a bachelor's degree, $76.8 \%(\mathrm{n}=$ $305)$, whereas $17.1 \%(n=114)$ were master's degree holders, with $6 \%(n=24)$ having a high school certificate or its equivalent. With respect of the respondents' area of work experience, $30 \%(\mathrm{n}=119)$ indicated that they have experience in general management while a similar number, that $104(26.2 \%)$ had experience in finance. Other areas of experience include accounting $(n=68,17.1 \%)$, risk management $(n=12,3 \%)$ and other units or departments within the various organizations $(n=70,17.6 \%)$. Majority of the respondents $(n=231,58.2 \%)$ belong to firms other than Energy, Oil and Gas and Mining, Finance, Banking, Insurance, Government, Education, Non-profit, Lumber, Furniture, Paper and Packaging, Manufacturing which includes all other telecom industry, fashion, etc. Most of the firms $(n=144,36.6 \%)$ had their annual revenue falling between $\mathrm{GH} \notin 250,000,000$ and $\mathrm{GH} \phi 500,000,00$. The researcher did not skew any of the above profiles to suit a particular parameter. All respondents were contacted and only 
partook in the exercise as a result of their availability and willingness to participate. In total, 397 valid responds were analysed.

\section{Confirmatory Factor Analysis}

To validate the scales used and test for convergent and discriminant validity, all independent and dependent latent variables were included in one multifactorial confirmatory model (CFA) with a robust maximum likelihood estimation method (MLR). To estimate the multifactorial CFA model, each item was specified to be loaded into its specific factor, and the error terms were independent, hence the measurements were unidimensional. The chi-square test statistic, comparative fit index (CFI), the Tucker-Lewis's index (TLI), and the root mean square error of approximation (RMSEA) served as the indices to assess the CFA model's goodness-of-fit (GOF). Values above the threshold of 0.90 for CFI and TLI and below 0.08 for RMSEA indicate a good fit of the model to the data (Kline, 2011). The results of the CFA indicate that the nine-factor model had an excellent fit with the data. The GOF values were as follows: $\chi 2 / \mathrm{df}=731.16 / 428$; CFI $=0.94$, TLI $=0.94$, and $\mathrm{RMSEA}=0.04[90 \%$ confidence interval (CI): 0.03-0.04]. The stand ardized RMR was 0.052.

\section{Hypothesis Testing}

To test the directional hypotheses, all the latent variables were included in a single structural model. The maximum likelihood estimator was used. The results of the path analysis indicate that the eight-factor structural model had a good fit to the data. The GOF values were as follows: $\mathrm{x} 2(\mathrm{df})=731.16(428)$; CFI $=0.96$, $\mathrm{TLI}=0.95$, and RMSEA $=0.04$ (90\% CI: 0.04-0.05). The Standardized RMR $=0.05$.

The results obtained reveal that board composition has a positive and significant influence on the economic dimension of CSR $(=0.412 ; \mathrm{t}$-value $=0.48$; $\mathrm{p}$-value $=0.63)$, leading to the acceptance of H1a. However, board composition did not have any influence or significant influence on the environmental dimension of CSR. Therefore, hypothesis H1b $(=0.001$; -value $=0.006$; p-value $=0.99)$, was also rejected. Similarly, board composition did not exhibit any significant influence on the social dimension of corporate social responsibility, which led to the rejection of hypotheses $\mathrm{H} 1 \mathrm{c}(=0.057$; $\mathrm{t}-$ value $=-0.041 ; \mathrm{p}$-value $=0.69)$. 
The findings of this study further reveal that board size had no significant relationship with the economic dimension of CSR, leading to the rejection of $\mathrm{H} 2 \mathrm{a}$ (= $0.07 ; \mathrm{t}$ - value $=0.32 ; \mathrm{p}$-value $=0.751)$. Nonetheless, board size had positive and significance influence on environmental dimension of CSR as well as social dimension of CSR, leading to the acceptance hypothesis $\mathrm{H} 2 \mathrm{~b}(\beta=2.76$; $\mathrm{t}$-value $=2.69 ; \mathrm{p}$ value $=$ $0.007)$ and $\mathrm{H} 2 \mathrm{c}(\beta=1.96$; $\mathrm{t}$-value $=3.29 ; \mathrm{p}$ value $=0.001)$ and respectively.

Institutional ownership showed no significant influence on economic dimension of $\mathrm{CSR}$, therefore $\mathrm{H} 3 \mathrm{a}$ was rejected $(\beta=-0.15 ; \mathrm{t}$-value $=-.0 .85 ; \mathrm{p}$ value $=0.40)$. However, institutional ownership showed a positive relationship with environmental dimension and social dimensions of CSR leading to the acceptance of $\mathrm{H} 3 \mathrm{~b}(\beta=1.47$; $\mathrm{t}$ value $=2.04 ; \mathrm{p}$ value $=0.04)$ and $\mathrm{H} 3 \mathrm{c}(\beta=1.19 ; \mathrm{t}$-value $=2.65 ; \mathrm{p}$ value $=0.008)$.

CEO- Chair Duality showed no influence on the economic dimension of CSR and this resulted in a rejection of $\mathrm{H} 4 \mathrm{a}(\beta=$; -value $=-0.897 ; \mathrm{p}$ value $=0.37)$. The results, however, indicated that CEO-Chair Duality had a negative influence on the environmental and social dimensions of CSR. Therefore, hypothesis H4b $(\beta=1.46$; $\mathrm{t}$ value $=2.012 \mathrm{p}$ value $=0.004)$ and $\mathrm{H} 4 \mathrm{c}(\beta=1.2 ; \mathrm{t}$-value $=2.7 ; \mathrm{p}$ value $=0.007)$ were confirmed.

The economic dimension of CSR had no significant influence on corporate sustainability, therefore H5a was rejected ( $=0.23$; $\mathrm{t}$-value $=-1.184 ; \mathrm{p}$ value $=0.236$. The environmental dimension of CSR had a positive relationship with corporate CSR, leading to the acceptance of $\mathrm{H} 5 \mathrm{~b}(=0.19 ; \mathrm{t}$-value $=2.638$; $\mathrm{p}$ value $=0.008)$. Similarly, the social dimension of CSR had a positive and significant influence on corporate sustainability, thus H5c $(=0.23 ; \mathrm{t}$-value $=3.186 ; \mathrm{p}$ value $=0.001)$ was confirmed . Presented in Table 1 is a summary of the computations relating to the tests of the hypotheses in this study. 
Table 1.: Path Analysis using SEM

\begin{tabular}{|l|l|l|l|l|l|}
\hline Hypothesis & Path & Beta & t-values & p-values & Result \\
\hline H1a & BC $\rightarrow$ CSR_EC & 0.41 & 5.53 & 0.001 & Accepted \\
& & & & & \\
\hline H1b & BC $\rightarrow$ CSR_EN & 0.001 & -0.02 & 0.99 & Rejected \\
\hline H1a & BC $\rightarrow$ CSR_S & -0.06 & -0.41 & 0.69 & Rejected \\
\hline H2a & BZ $\rightarrow$ CSR_EC & 0.08 & 0.327 & 0.74 & Rejected \\
\hline H2b & BZ $\rightarrow$ CSR_EN & 2.76 & 2.69 & 0.007 & Accepted \\
\hline H2c & BZ $\rightarrow$ CSR_S & 1.96 & 3.29 & 0.001 & Accepted \\
\hline H3a & INO $\rightarrow$ CSR_EC & -0.15 & -0.897 & 0.39 & Rejected \\
\hline H3b & INO $\rightarrow$ CSR_EN & 1.47 & 2.04 & 0.04 & Accepted \\
\hline H3c & INO $\rightarrow$ CSR_S & 1.19 & 2.65 & 0.008 & Accepted \\
\hline H4a & CCD $\rightarrow$ CSR_EC & 0.03 & -0.08 & 0.93 & Rejected \\
\hline H4b & CCD $\rightarrow$ CSR_EN & -3.76 & -2.49 & 0.001 & Accepted \\
\hline H4c & CCD $\rightarrow$ CSR_S & -2.77 & -3.14 & 0.002 & Accepted \\
\hline H5a & CSR_EC $\rightarrow$ CSU & 0.07 & -1.184 & 0.236 & Rejected \\
\hline H5b & CSR_EN $\rightarrow$ CSU & 0.19 & 2.638 & 0.008 & Accepted \\
\hline H5a & CSR_S $\rightarrow$ CSU & 0.23 & 3.186 & 0.001 & Accepted \\
\hline
\end{tabular}

Source: Field Data, 2021

Notes: CSR_S = Corporate Social Responsibility (Social Dimension); CSR_EN = Corporate Social Responsibility (Environmental Dimension); CSR_EC = Corporate Social Responsibility (Economic Dimension); BC = Board composition; BZ =Board

Size; INO = Institutional Ownership; CCD = CEO- Chair Duality; TP= Top

Management Commitment; CSU= Corporate sustainability

\section{Moderation Analysis}

To test for the moderation effects, Amos 24 with 2,000 bootstrap samples was used. Since no significant relationship was found between the relationships that exist between the economic dimension of CSR and corporate sustainability, and the moderating effect of top management commitment on these relationships, they were not tested. Therefore, H6a is rejected as top management commitment was found to not moderate the relationship between the economic dimension of CSR and corporate sustainability. However, the interactive effect of top management commitment on the relationship between the environmental dimension of CSR and corporate sustainability was found to be significant $(\gamma(\mathrm{S} . \mathrm{E})=0.026, \mathrm{p}=0.01)$. The significant interactive effect indicated that top management commitment is a moderator within the environmental dimension of CSR and corporate sustainability. Hence, H6b was confirmed. The moderating role of top management commitment was not tested in the relationship between the social dimension and corporate sustainability, as the result further indicates that there was no significant interaction between the social dimension and corporate sustainability. Therefore, hypothesis H6c is rejected. Following Aiken and West's (1991) recommendation to probe these interactions, this research drew an interaction plot and the unstandardized estimates are plotted onto the '2-Way Interaction 
Tab in the Statistical Tools Package in MS Excel (Gaskin, 2012), which has been illustrated graphically in Figure 2. This was to illustrate the change in slopes across varying levels of the moderator. The graph indicates that top management commitment strengthens the positive relationship between the environmental dimension of CSR and corporate sustainability.

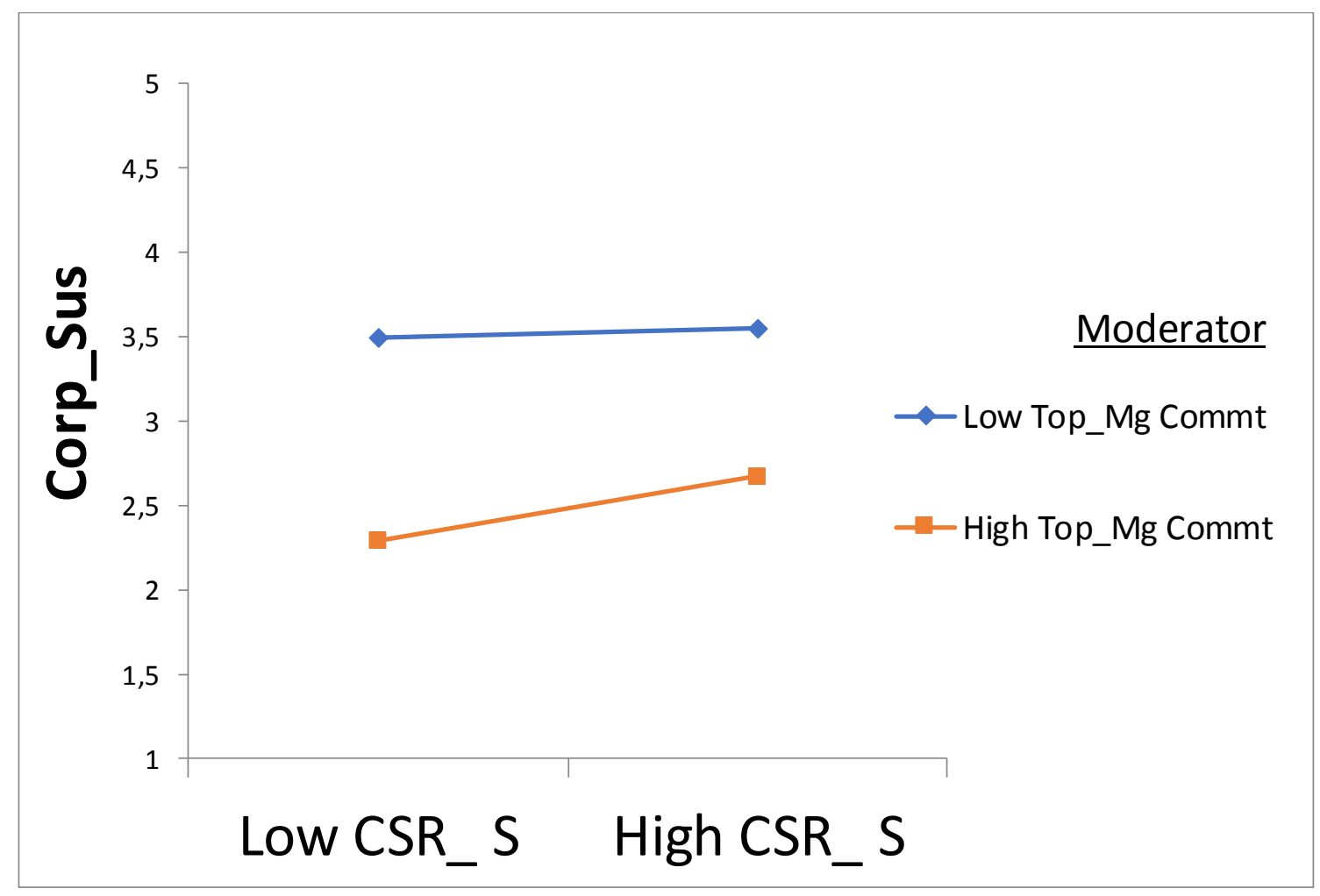

Figure 2: Change in slopes across varying levels of the moderator Source: Field Data, 2021

\section{DISCUSSION}

Relationship between Corporate Governance and Corporate social Responsibility

The findings of this study indicate mixed relationships between the various corporate governance indices and the dimensions of corporate social responsibility. The findings agree with the assertion by Young and Thyil (2014) that governance systems and their interactions with CSR are fluid in accordance with changes in the national and institutional framework, economic conditions, and industry impact. As indicated by Karim et al. (2020), there have been mixed results regarding the relationship between board composition and CSR. Results indicate that board composition positively influenced the economic dimension of CSR. However, board composition did not influence the social and environmental dimensions. This partly confirms the findings of 
Lau et al. (2016), where board composition was found to have no significant influence on CSR. Cultural and economic differences could account for these differences as national cultural dimensions have been found to both positively and negatively impact CSR performance depending on a given dimension of CSR (Thanetsunthorn, 2015). These results imply that board composition plays an influential role in impacting on how firms work to increase profitability, ensure sustainability and, at the same time, strategically position firms to compete favourably against competitors and maintain market value.

In addition, board size exerted varying influence on the various dimensions of CSR. The findings of this study found that board size had no significant relationship with the economic dimension of CSR, but board size showed a positive and significant influence on the environmental dimension of CSR as well as the social dimension of CSR. These findings confirm the assertion by Rouf and Hossan (2021) that there are contradictory findings regarding the relationship between board size and CSR. Similar to the results obtained for board size, institutional ownership showed no significant influence on economic dimension of CSR, but had a positive relationship with environmental dimension and social dimensions of CSR. The differences observed from these findings indicate that board size and institutional ownership have impact on how firms churn out their environmental and social dimensions of CSR.

Furthermore, as expected, CEO-Chair Duality had a negative influence on the environmental and social dimensions of CSR but failed to have any influence on the economic dimension of CSR. It can therefore be said that CEO-Chair Duality impacts how firms perform their social and environmental responsibilities, as CEO-Duality concentrates power and major decision-making on only one person. Therefore, for effective implementation of the environmental and social dimensions of CSR, firms must ensure that the roles of CEO and board chair are separated. Contrary to expectations, the economic dimension of CSR had no significant influence on corporate sustainability. However, the positive relationship between the environmental and social dimensions of CSR and corporate sustainability was confirmed.

\section{Moderating Role of Top Management Commitment}

The study failed to find any moderating effect of top management commitment on the relationship between the economic dimension of CSR and corporate 
sustainability. Similarly, the moderating role of top management commitment was not tested in the relationship between the social dimension and corporate sustainability, as the result further indicates that there was no significant interaction between the social dimension and corporate sustainability. However, the moderating role of top management commitment was confirmed for the relationship between the environmental dimension of CSR and corporate sustainability. These findings imply that top management commitment plays a partial role in influencing the CSR activities that could lead to the achievement of corporate sustainability goals.

\section{THEORETICAL IMPLICATIONS}

The findings of this study have some theoretical implications. The presented study has tried to link how corporate governance measures contribute to the promotion of corporate social responsibility in the context of manufacturing firms in Ghana. The study has tried to bring forward the inter-linkages between three different research streams, i.e., corporate governance, corporate social responsibility, and corporate sustainability. Even though previous studies have highlighted the link between these constructs, the examination of these linkages within a single study is sparse. Therefore, this study contributes to the extension of the understanding of how corporate governance fosters CSR activities, which in turn impacts firms' corporate sustainability achievement. Furthermore, the findings of the study point out the differences in how the various indicators of corporate governance relate to the various dimensions of CSR. Thus, the theoretical understanding of these linkages is expanded. In addition, this study adds to the existing body of literature on the linkage between CSR and corporate sustainability by examining the moderating effect of top management commitment on the link between CSR and corporate sustainability. The findings extend the theoretical understanding of the conditions under which certain various dimensions of CSR can promote corporate sustainability. Further, the study findings advance the social exchange theory, which gives an explanation that employees would exhibit innovative behavior when they perceive that HR-practices that are directed at them are beneficial. Then they would reciprocate this gesture by displaying innovative behavior. Further contributions to this study come from the empirical evidence from a developing country context in sub-Saharan Africa. The distribution of literature in the current research strongly reveals that most of the extant works are concentrated in developing 
economies, which are less represented regions, with a few studies from Africa. As a result, there is relatively scarce evidence from developing economic contexts.

\section{MANAGERIAL IMPLICATIONS}

The findings of this study have some managerial implications. First, the study findings suggest some characteristics of CSR can play an influential role in CSR, which would influence the achievement of firms' sustainability goals, while others tend to negatively influence CSR activities. The results therefore highlight the crucial role played by these corporate governance characteristics in their contribution to the achievement of business sustainability. Therefore, all stakeholders must be involved to ensure that proper controls are put in place within firms, as these will foster the achievement of sustainability goals.

\section{LIMITATION AND DIRECTIONS FOR FUTURE RESEARCH}

There were several limitations to this study that need to be mentioned. First, this research was limited to the manufacturing industry. In addition, this study was limited to Ghana, an emerging economy with unique socio- cultural dynamics. Organizational culture and national culture were the results obtained for this study. As a result, the findings may not be reflective of the views of industries in other geographical locations. Secondly, only four indicators of governance were considered for this study. Therefore, caution should be taken when interpreting and generalizing the findings in respect to the other characteristics of corporate governance. Even though, the likelihood that the findings are influenced by common method bias was limited, data was collected at the same point-at the time. Because of its cross-sectional research design, this study cannot firmly establish causality among the study variables.

Based on the findings emanating from this research as well as the limitations outlined above, this suggests the need for further research in the area under study. First, future studies can be conducted in other industries and other countries to confirm the results obtained from this study, as different results may be obtained due to differences in organizational culture and national culture. In addition, it would also be interesting to conduct a comparable study to compare the results obtained here in this emerging economy with those of a developed economy. In addition, the influence of other moderators and mediators could be examined to understand their effect on the link 
between corporate governance, CSR, and corporate sustainability. Furthermore, future studies can consider other indicators of corporate governance and assess their influence on the various dimensions of CSR as well as their linkage with the three dimensions of corporate sustainability. Longitudinal studies may be conducted to establish causal relationships between the variables examined. In addition, a mixed-method approach could be conducted to explore and establish a deeper understanding of the results obtained.

\section{REFERENCES}

Abad-Segura, E., Joaqu, F., \& Belmonte-ureña, L. J. (2019). The Sustainable Approach to Corporate Social Responsibility: A Global Analysis and Future Trends. Sustainability, 11(19), 5382. https://doi.org/10.3390/su11195382

Abu Qa'dan, M. B., \& Suwaidan, M. S. (2019). Board composition, ownership structure and corporate social responsibility disclosure: the case of Jordan. Social Responsibility Journal, 15(1), 28-46. https://doi.org/10.1108/SRJ-11-2017-0225

Ajayi, V. O. (2017). Primary Sources of Data and Secondary Sources of Data. September, 1-6. https://doi.org/10.13140/RG.2.2.24292.68481

Al-thuneibat, A. A., Al-Angari, H. A., \& Al-Saad, S. A. (2016). The effect of corporate governance mechanisms on earnings management Evidence from Saudi Arabia. Review of International Business and Strategy, 26(1), 2-32. https://doi.org/10.1108/RIBS-10$\underline{2013-0100}$

Alabdullah, T. T. Y., Ahmed, E. R., \& Muneerali, M. (2019). Effect of Board Size and Duality on Corporate Social Responsibility: What has Improved in Corporate Governance in Asia? Journal of Accounting Science, 3(2), 121-135. https://doi.org/10.21070/jas.v3i2.2810

Alabdullah, T. T. Y., Laadjal, A., Ahmed, E. R., \& Al-Asadi, Y. A. A. (2018). Board Features and Capital Structure in Emerging Markets. Journal of Advanced Management Science, 6(2), 74-80. https://doi.org/10.18178/joams.6.2.74-80

Alvarado-herrera, A. A., Bigne, E., Aldas-manzano, J., Enrique, A. A., Joaquín, B., \& Curras-perez, R. (2017). A Scale for Measuring Consumer Perceptions of Corporate Social Responsibility Following the Sustainable Development Paradigm. A Scale for Measuring Consumer Perceptions of Corporate Social Responsibility Following the Sustainable Development Paradigm. Journal of Business Ethics, 140(2), 243-262.

Amoako, G. K. (2017). Relationship Between Corporate Social Responsibility (CSR) and Corporate Governance (CG): The Case of Some Selected Companies in Ghana. 151174. https://doi.org/10.1007/978-3-319-55206-4_9 
Appelbaum, E., Bailey, T., Berg, P., Kalleberg, A. L., \& Bailey, T. A. (2000). Manufacturing Advantage_ Why High-performance Work Systems Pay Off. Ithaca, NY; Cornell University Press.

Arrive, T. J., Feng, M., Yan, Y., \& Chege, S. M. (2019). The involvement of telecommunication industry in the road to corporate sustainability and corporate social responsibility commitment. Corporate Social Responsibility and Environmental Management, 26(1), 152-158. https://doi.org/10.1002/csr.1667

Ashrafi, M., Adams, M., Walker, T. R., \& Magnan, G. (2018). 'How corporate social responsibility can be integrated into corporate sustainability: a theoretical review of their relationships.' International Journal of Sustainable Development and World Ecology, 25(8), 671-681. https://doi.org/10.1080/13504509.2018.1471628

Ashrafi, Mehrnaz, Magnan, G. M., Adams, M., \& Walker, T. R. (2020). Understanding the Conceptual Evolutionary Path and Theoretical Underpinnings of Corporate Social Responsibility and Corporate Sustainability.

Bagozzi, R. P. (1992). The Self-Regulation of Attitudes, Intentions, and Behavior. Social Psychology Quarterly, 55(2), 178-204.

Bagozzi, R. P., \& Yi, Y. (1988). On the evaluation of structural equation models. Journal of the Academy of Marketing Science, 16(1), 74-94. https://doi.org/10.1007/BF02723327

Bansal, P., \& Desjardine, M. R. (2014). Business sustainability: It is about time. Strategic Organization, 12(1), 70-78. https://doi.org/10.1177/1476127013520265

Bansal, P., \& Song, H. C. (2017). Similar but not the same: Differentiating corporate sustainability from corporate responsibility. Academy of Management Annals, 11(1), 105-149. https://doi.org/10.5465/annals.2015.0095

Bhatt, P. R., \& Bhatt, R. R. (2017). Corporate governance and firm performance in Malaysia. Corporate Governance, 17(5), 896-912. https://doi.org/10.1108/CG-03$\underline{2016-0054}$

Brown, L. D., \& Caylor, M. L. (2006). Corporate governance and firm valuation. Journal of Accounting and Public Policy, 25, 409-434. https://doi.org/10.1016/j.jaccpubpol.2006.05.005

Bux, H., Zhang, Z., \& Ahmad, N. (2020). Promoting sustainability through corporate social responsibility implementation in the manufacturing industry: An empirical analysis of barriers using the ISM-MICMAC approach. Corporate Social Responsibility and Environmental Management, 27, 1729-1748. https://doi.org/10.1002/csr.1920

Camilleri, M. A. (2017). Corporate sustainability and responsibility: creating value for business, society and the environment. https://doi.org/10.1186/s41180-017-0016-5

Cantele, S., \& Zardini, A. (2018). Is sustainability a competitive advantage for small businesses? An empirical analysis of possible mediators in the sustainability financial performance relationship. Journal of Cleaner Production, 182, 166-176. https://doi.org/10.1016/i.jclepro.2018.02.016 
Carroll, A. B., Carroll, A. B., Brown, J., Carroll, A. B., \& Carroll, A. B. (2015). Corporate Social Responsibility: The Centerpiece of Competing and Complementary Frameworks Related Papers Corporate social responsibility: The centerpiece of competing and complementary frameworks. Organizational Dynamics, 44(2), 87-96.

Carroll, A. B., \& Shabana, K. M. (2010). The Business Case for Corporate Social Responsibility: A Review of Concepts, Research and Practice. International Journal of Management Reviews, 12(1), 85-105. https://doi.org/10.1111/j.1468$\underline{2370.2009 .00275 . \mathrm{x}}$

Choi, S., \& Ng, A. (2011). Environmental and Economic Dimensions of Sustainability and Price Effects on Consumer Responses. Journal of Business Ethics, 104(2), 269-282.

Chow, W. S., \& Chen, Y. (2012). Corporate Sustainable Development: Testing a New Scale Based on the Mainland Chinese Context. Journal of Business Ethics, 105(4), 519-533. https://doi.org/10.1007/s

Churchill, G. A., \& Iacobucci, D. (2006). Marketing research: methodological foundation s. New York: Dryden Press.

Ciftci, I., Tatoglu, E., Wood, G., Demirbag, M., \& Zaim, S. (2019). Corporate governance and firm performance in emerging markets: Evidence from Turkey. International Business Review Journal, 28(August 2018), 90-103. https://doi.org/10.1016/j.ibusrev.2018.08.004

Crane, A. D., Michenaud, S., \& Weston, J. P. (2016). The Effect of Institutional Ownership on Payout Policy: Evidence from Index Thresholds. Review of Financial Studies, 29(6), 1377-1408. https://doi.org/10.1093/rfs/hhw012

Crifo, P., Escrig-Olmedo, E., \& Mottis, N. (2019). Corporate Governance as a Key Driver of Corporate Sustainability in France: The Role of Board Members and Investor Relations. Journal of Business Ethics, 159(4), 1127-1146. https://doi.org/10.1007/s10551-018-3866-6

Currás-Pérez, R., Dolz-Dolz, C., Miquel-Romero, M. J., \& Sánchez-García, I. (2018). How social, environmental, and economic CSR affects consumer-perceived value: Does perceived consumer effectiveness make a difference? Corporate Social Responsibility and Environmental Management, 25(5), 733-747. https://doi.org/10.1002/csr.1490

Dahlsrud, A. (2008). How Corporate Social Responsibility is Def ined: An Analysis of 37 Definitions. Corporate Social Responsibility and Environmental Management, 15(1), 1-13. https://doi.org/10.1002/csr.132

Davis, K. (1973). The Case for and Against Business Assumption of Social Responsibilities'. The Academy of Management Journal, 16(2), 312-322.

Dewi, I. G.., Riana, I. G., Kasuma, J., Mcguinness, E., Maria, S., \& Darma, D. C. (2021). Predicting

organizational citizenship behavior through psychological ownership and job satisfaction in four-star hotels. Geo Journal of Tourism and Geosites, 37(3), 807-813. https://doi.org/10.30892/gtg.37310-712 
Dwekat, A., Seguí-mas, E., \& Tormo-carbó, G. (2020). The effect of the board on corporate social responsibility: bibliometric and social network analysis. Economic ResearchEkonomska Istraživanja, 33(1), 3580-3603. https://doi.org/10.1080/1331677X.2020.1776139

Dyllick, T., \& Hockerts, K. (2002). Beyond the business case for corporate sustainability. Business Strategy and the Environment, 11, 130-141.

Dyllick, T., \& Muff, K. (2016). Clarifying the Meaning of Sustainable Business: Introducing a Typology from Business-as-Usual to True Business Sustainability. Organization and Environment, 29(2), 156-174. https://doi.org/10.1177/1086026615575176

Erdogan, B., Bauer, T. N., \& Taylor, S. (2015). Management commitment to the ecological environment and employees: Implications for employee attitudes and citizenship behaviors Berrin Erdogan. Human Relations, 68(11), 1669-1691. https://doi.org/10.1177/0018726714565723

Erhemjamts, O., \& Huang, K. (2019). Institutional ownership horizon, corporate social responsibility and shareholder value. Journal of Business Research, 105(January 2018), 61-79. https://doi.org/10.1016/j.jbusres.2019.05.037

Fuente, J. A., García-Sánchez, I. M., \& Lozano, M. B. (2016). The role of the board of directors in the adoption of GRI guidelines for the disclosure of CSR information. Journal of Cleaner Production, 141, 737-750. https://doi.org/10.1016/j.jclepro.2016.09.155

García-Meca, E., \& Palacio, C. J. (2018). Board composition and firm reputation: The role of business experts, support specialists and community influential. BRQ Business Research Quarterly, 21(2), 111-123. https://doi.org/10.1016/j.brq.2018.01.003

Garver, M. S., \& Mentzer, J. T. (1999). Logistics research methods: employing structural equation modeling to test for construct validity. Journal of Business Logistics, 20(1), 33.

Gavronski, I., Klassen, R. D., Vachon, S., \& do Nascimento, L. F. M. (2011). A resourcebased view of green supply management. Transportation Research Part E: Logistics and Transportation Review, 47(6), 872-885. https://doi.org/10.1016/j.tre.2011.05.018

Goyal, P., \& Kumar, D. (2017). Modeling the CSR barriers in manufacturing industries. Benchmarking, 24(7), 1871-1890. https://doi.org/10.1108/BIJ-09-2015-0088

Hadi, N., \& Udin, U. (2021). Testing the Effectiveness of CSR Dimensions for Small Business Entrepreneurs. Journal of Open Innovation: Technology, Market, and Complexity, 7(6), 1-15.

Hahn, T., Figge, F., Aragón-Correa, J. A., \& Sharma, S. (2017). Advancing Research on Corporate Sustainability: Off to Pastures New or Back to the Roots? Business and Society, 56(2), 155-185. https://doi.org/10.1177/0007650315576152 
Hahn, T., Pinkse, J., Preuss, L., Figge, F., Journal, S., March, N., Hahn, T., Lutz, P., \& Figge, F. (2015). Tensions in Corporate Sustainability: Towards an Integrative Framework Tensions in Corporate Sustainability: Towards an Integrative. Journal of Business Ethics, 127(2), 297-316. https://doi.org/10.1007/s10551-014-2047-5

Haniffa, R. M., \& Cooke, T. E. (2002). Culture, Corporate Governance and Disclosure in Malaysian Corporations. 38(3), 317-349.

Henry, L. A., Buyl, T., \& Jansen, R. J. G. (2019). Leading corporate sustainability: The role of top management team composition for triple bottom line performance. September 2018, 173-184. https://doi.org/10.1002/bse.2247

Hoe, S. L. (2008). Issues and procedures in adopting structural equation modelling technique. Journal of Quantitative Methods, 3(1), 76-83.

Hu, K., Lin, S., \& Hsu, M. (2018). A Fusion Approach for Exploring the Key Factors of Corporate Governance on Corporate Social Responsibility Performance. https://doi.org/10.3390/su10051582

Hussain, N., Rigoni, U., \& Orij, R. P. (2018). Corporate Governance and Sustainability Performance: Analysis of Triple Bottom Line Performance. Journal of Business Ethics, 149(2), 411-432. https://doi.org/10.1007/s10551-016-3099-5

Iacobucci \& Churchill. (2018). Order directly from Amazon: Marketing Research: September.

Iacobucci, D. (2009). Everything you always wanted to know about SEM (structural equations modeling) but were afraid to ask. Journal of Consumer Psychology, 19(4), 673-680. https://doi.org/10.1016/j.jcps.2009.09.002

Jiang, K., Lepak, D. P., Hu, J., \& Baer, J. C. (2012). How does human resource management influence organizational outcomes? A meta-analytic investigation of mediating mechanisms. Academy of Management Journal, 55(6), 1264-1294.

Jizi, M. I., Salama, A., Dixon, R., \& Stratling, R. (2013). Corporate Governance and Corporate Social Responsibility Disclosure: Evidence from the US Banking Sector. Journal of Business Ethics, 125(4), 601-615. https://doi.org/10.1007/s10551-013$\underline{1929-2}$

Jo, H., \& Harjoto, M. A. (2012). The causal effect of corporate governance on corporate social responsibility. Journal of Business Ethics, 106(1), 53-72. https://doi.org/10.1111/ajfs.12121

Karim, S., Manab, N. A., \& Ismail, R. B. (2020). The dynamic impact of board composition on CSR practices and their mutual effect on organizational returns. Journal of Asia Business Studies, 14(4), 463-479. https://doi.org/10.1108/JABS-07-2019-0214

Kim, M., Yin, X., \& Lee, G. (2020). The effect of CSR on corporate image, customer citizenship behaviors, and customers' long-term relationship orientation. International Journal of Hospitality Management, 88(February), 102520. https://doi.org/10.1016/j.ijhm.2020.102520 
Kyere, M., \& Ausloos, M. (2021). Corporate governance and firm's financial performance in the United Kingdom. International Journal of Finance and Economics, 26(2), 18711885. https://doi.org/10.1002/ijfe.1883

Laszlo, C., \& Zhexembayeva, N. (2011). Embedded Sustainability: A strategy for market leaders. European Financial Review, April-May, 38-41.

Lau, C., Lu, Y., Liang, Q., Journal, S., June, N., Lau, C., Lu, Y., \& Liang, Q. (2016). Corporate Social Responsibility in China: A Corporate Governance Approach Corporate Social Responsibility in China: A Corporate Governance Approach. Journal of Business Ethics, 136(1), 73-87. https://doi.org/10.1007/s10551-014-2513-0

Lepak, D. P., Liao, H., Chung, Y., \& Harden, E. E. (2006). A Conceptual Review of Human Resource Management Systems in Strategic Human Resource Management Research. Research in Personnel and Human Resources Management, 25(06), 217-271. https://doi.org/10.1016/S0742-7301(06)25006-0

Lin, Y. R., \& Fu, X. M. (2017). Does institutional ownership influence firm performance? Evidence from China. International Review of Economics and Finance, 49(January), 17-57. https://doi.org/10.1016/j.iref.2017.01.021

Lozano, R. (2015). A Holistic Perspective on Corporate Sustainability Drivers. April 2013, 32-44. https://doi.org/10.1002/csr.1325

Luo, J. M., Huang, G. Q., \& Lam, C. F. (2019). Barriers to the Implementation of Corporate Social Responsibility in Gaming Industry. Journal of Quality Assurance in Hospitality \& Tourism, 00(00), 1-24. https://doi.org/10.1080/1528008X.2018.1563019

MacLean, S., \& Gray, K. (1998). Structural Equation Modelling in Hospitality Research. Journal of the Australian Market Research Society, 6(1), 17-32. https://doi.org/10.1177/146735840000200110

Marrewijk, M. van. (2003). Concepts and Definitions of CSR and Corporate Sustainability: Between Agency and Communion. Journal of Business Ethics, 44(2), 94-105.

Martínez, P., Pérez, A., Rodríguez, I., Andrea, P., \& Rodrı, I. (2014). CSR influence on hotel brand image and loyalty. Academia Revista Latinoamericana de Administración, 27(2), 267-283. https://doi.org/10.1108/ARLA-12-2013-0190

Matten, D., \& Moon, J. (2008). "Implicit" and "explicit" CSR: A conceptual framework for a comparative understanding of corporate social responsibility. Academy of Management Review, 33(2), 404-424.

Meuer, J., Koelbel, J., \& Hoffmann, V. H. (2019). On the Nature of Corporate Sustainability. https://doi.org/10.1177/1086026619850180

Michelon, G., \& Parbonetti, A. (2012). The effect of corporate governance on sustainability disclosure. 477-509. https://doi.org/10.1007/s10997-010-9160-3

Montiel, I., \& Delgado-Ceballos, J. (2014). Defining and Measuring Corporate Sustainability: Are We There Yet? Organization and Environment, 27(2), 113-139. https://doi.org/10.1177/1086026614526413 
Naciti, V. (2019). Corporate governance and board of directors: The effect of a board composition on fi rm sustainability performance. Journal of Cleaner Production, 237, 117727. https://doi.org/10.1016/j.jclepro.2019.117727

Nazar, M. C. A. (2016). Does CEO Duality affect the Firm Performance? Evidence from Sri Lanka. International Journal of Advances in Agriculture Sciences, 15(2), 5-14.

Nurleni, N., Bandang, A., Darmawati, \& Amiruddin. (2018). The effect of managerial and institutional ownership on corporate social responsibility disclosure. International Journal of Law and Management, 60(4), 979-987. https://doi.org/10.1108/IJLMA-03$\underline{2017-0078}$

Ofori, D. F. (2008). Executive and management attitudes on social responsibility and ethics in Ghana: Some initial exploratory insights. Unpublished manuscript. Department of Organization \& HRM, University of Ghana Business School, University of Ghana, Legon.

Oh, W. Y., Cha, J., \& Chang, Y. K. (2017). Does Ownership Structure Matter? The Effects of Insider and Institutional Ownership on Corporate Social Responsibility. Journal of Business Ethics, 146(1), 111-124. https://doi.org/10.1007/s10551-015-2914-8

Olthuis, B. R., \& van den Oever, K. F. (2020). The board of directors and CSR: How does ideological diversity on the board impact CSR? Journal of Cleaner Production, 251, 119532. https://doi.org/10.1016/j.jclepro.2019.119532

Palaniappan, G. (2017). Determinants of corporate financial performance relating to board characteristics of corporate governance in Indian manufacturing industry an empirical study. European Journal of Management and Business Economics, 26(1), 67-85. https://doi.org/10.1108/EJMBE-07-2017-005

Pintea, M. (2015). Relationship between Corporate Governance and CSR Fit. Pintea, Mirela-Oana. "The Relationship between Corporate Governance and Corporate Social Responsibility." Review of Economic Studies and Research Virgil Madgearu, 8(4), 91108. https://doi.org/10.5762/KAIS.2019.20.6.104

Rahi, S. (2017). Research Design and Methods: A Systematic Review of Research Paradigms, Sampling Issues and Instruments Development, International Journal of Economics 6(2). https://doi.org/10.4172/2162-6359.1000403

Ratnasari, S. L., Rahmawati, R., Ramadania, R., Darma, D. C., \& Sutjahjo, G. (2021). Ethical work climate in motivation and moral awareness perspective: the dilemma by the Covid-19 crisis? Journal Public Policy and Administration, 20(4), 398-409. https://doi.org/10.13165/VPA-21-20-4-04

Raut, R. (2018). An ISM approach for the barrier analysis in implementing sustainable practices. Benchmarking: An International, 25(4), 1245-1271. https://doi.org/10.1108/BIJ-05-2016-0073

Rouf, M. A., \& Hossan, M. A. (2021). The effects of board size and board composition on CSR disclosure: a study of banking sectors in Bangladesh. International Journal of Ethics and Systems, 37(1), 105-121. https://doi.org/10.1108/IJOES-06-2020-0079 
Ruggiero, P., \& Cupertino, S. (2018). CSR Strategic Approach, Financial Resources and Corporate Social Performance: The Mediating Effect of Innovation. Sustainability, 10(10), 3611. https://doi.org/10.3390/su10103611

Sarkar, S., \& Searcy, C. (2016). Zeitgeist or chameleon? A quantitative analysis of CSR definitions. Journal of Cleaner Production, 135, 1423-1435. https://doi.org/10.1016/j.jclepro.2016.06.157

Saunders, M. N. K., Lewis, P., \& Thornhill, A. (2019). Research Methods for Business Students (8th Editio). Pearson Education Limited. www.pearson.com/uk

Sharma, J. P., \& Khanna, S. (2014). Corporate Social Responsibility, Corporate Governance and Sustainability: Synergies and. Indian Journal of Corporate Governance, 7(1), 14-38. https://doi.org/10.1177/0974686220140102

Stuebs, M., \& Sun, L. (2015). Corporate governance and social responsibility. International Journal of Law and Management, 57(1), 38-52. https://doi.org/10.1108/IJLMA-04$\underline{2014-0034}$

Terjesen, S., Aguilera, R. V, Lorenz, R., Journal, S., May, N., Terjesen, S., Aguilera, R. V, \& Lorenz, R. (2015). Legislating a Woman's Seat on the Board: Institutional Factors Driving Gender Quotas for Boards of Directors Legislating a Woman's Seat on the Board: Institutional Factors Driving Gender Quotas for Boards of Directors. Journal of Business Ethics, 128(2), 233-251. https://doi.org/10.1007/s

Thanetsunthorn, N. (2015). The impact of national culture on corporate social responsibility: evidence from cross-regional comparison. Asian Journal of Business Ethics, 4, 35-56. https://doi.org/10.1007/s13520-015-0042-2

Turker, D. (2009). Linked references are available on JSTOR for this article: Measuring Corporate Social Responsibility: A Scale Development Study. Journal of Business Ethics, 85(4), 411-427.

Young, S., \& Thyil, V. (2014). Corporate Social Responsibility and Corporate Governance: Role of Context in International Settings. Journal of Business Ethics, 122(1), 1-24.

Yusliza, M. Y., Norazmi, N. A., Jabbour, C. J. C., Fernando, Y., Fawehinmi, O., \& Seles, B. M. R. P. (2019). Top management commitment, corporate social responsibility and green human resource management: A Malaysian study. Benchmarking: An International, 26(6), 2051-2078. https://doi.org/10.1108/BIJ-09-2018-0283

Zhang, Q., Oo, B. L., Teck, B., \& Lim, H. (2018). Drivers, motivations, and barriers to the implementation of Corporate Social Responsibility practices by construction enterprises : A review. Journal of Cleaner Production, 210, 563-584. https://doi.org/10.1016/j.jclepro.2018.11.050

Zhuang, Y., Chang, X., \& Lee, Y. (2018). Board composition and corporate social responsibility performance: Evidence from Chinese public firms. Sustainability (Switzerland), 10(8). https://doi.org/10.3390/su10082752 
Zou, Z., Liu, Y., Ahmad, N., Sial, M. S., Badulescu, A., Zia-ud-din, M., \& Badulescu, D. (2021). What Prompts Small and Medium Enterprises to Implement CSR? A Qualitative Insight from an Emerging Economy. Sustainability, 13(952), 1-16.

\section{Contribution of Authors}

Every author should account for at least one component of the work. Paper approved for publication need to specify the contribution of every single author.

\begin{tabular}{|c|c|c|c|c|}
\hline Contribution & [Author 1] & [Author 2] & [Author 3] & [Author 4] \\
\hline 1. Definition of research problem & $\sqrt{ }$ & & & $\sqrt{ }$ \\
\hline $\begin{array}{l}\text { 2. Development of hypotheses or research } \\
\text { questions (empirical studies) }\end{array}$ & & & $\sqrt{ }$ & \\
\hline $\begin{array}{l}\text { 3. Development of theoretical propositions } \\
\text { (theoretical work) }\end{array}$ & $\sqrt{ }$ & & $\sqrt{ }$ & \\
\hline 4. Theoretical foundation / Literature review & & $\sqrt{ }$ & & \\
\hline 5. Definition of methodological procedures & $\sqrt{ }$ & & & \\
\hline 6. Data collection & & & & $\sqrt{ }$ \\
\hline 7. Statistical a nalysis & & $\sqrt{ }$ & & \\
\hline 8. Analysis and interpretation of data & $\sqrt{ }$ & & $\sqrt{ }$ & $\sqrt{ }$ \\
\hline 9. Critical revision of the manuscript & & $\sqrt{ }$ & & \\
\hline 10. Manuscript writing & & & & $\sqrt{ }$ \\
\hline 11. Other (please specify) & & & & \\
\hline
\end{tabular}

